\title{
Spatio-temporal Analysis Dynamics of the Landscape in the Classified Forest of Koulbi, Southwestern of Burkina Faso
}

\author{
Zézouma Sanon $^{1,2,{ }^{*}, \text { Mipro Hien }}{ }^{2}$, Boalidioa Tankoano ${ }^{2}$, Martin Karlson ${ }^{3}$, Irénée Somda ${ }^{2}$ \\ ${ }^{1}$ Department of Environment and Forests, Institute for Environmental and Agricultural Research, Ouagadougou, Burkina Faso \\ ${ }^{2}$ Institute for Rural Development, Nazi Boni University, Bobo-Dioulasso, Burkina Faso \\ ${ }^{3}$ Department of Thematic Studies/Environmental Change, Linköping University, Linköping, Sweden
}

Email address:

zezoumasanon@yahoo.fr (Z. Sanon),miphien@gmail.com (M. Hien), btankus67@yahoo.fr (B. Tankoano), martin.karlson@liu.se (M. Karlson), ireneesomda@yahoo.fr (I. Somda)

${ }^{*}$ Corresponding author

\section{To cite this article:}

Zézouma Sanon, Mipro Hien, Boalidioa Tankoano, Martin Karlson, Irénée Somda. Spatio-temporal Analysis Dynamics of the Landscape in the Classified Forest of koulbi, Southwestern of Burkina Faso. International Journal of Natural Resource Ecology and Management. Vol. 4, No. 6, 2019, pp. 205-215. doi: 10.11648/j.ijnrem.20190406.17

Received: November 21, 2019; Accepted: December 16, 2019; Published: December 25, 2019

\begin{abstract}
Most of the protected areas in Burkina Faso are affected by deforestation and forest degradation. This study is done in order to analysis the spatial and temporal dynamics of the classified forest of Koulbi and to identify the drivers of deforestation in the forest. For that, three Landsat images from 1986, 1998 and 2014 were exploited. The supervised classification based on the artificial neural network algorithm, under the ENVI software, was used. A transition matrix was established to analyze land use/land cover changes. The standardized precipitation index of 1985 to 2014 was used to access climate trend. Survey data from riverside villages and field observations were used to assess the human impact. The results show that between 1986 and 2014, the woodlands and tree savannas areas were reduced by 7\% and 0.49\% per year, respectively. However, substantial yearly increases in the areas of shrub savanna (2.8\%) and agricultural fields (1.4\%) were observed. During this period, the rainfall had a sharp trend towards aridity, with 18 years of drought against 12 years of humidity. This show that deficit of rainfall is increase. The socio-economic survey revealed that the classified forest used to be highly occupied and $64 \%$ of the inhabitants were yam producers. Cattle breeders and gold diggers have also been observed. We conclude that human activities are the main cause of degradation of the vegetation cover of the Koulbi classified forest. And climatic factors to some extent. It will be necessary to take actions to better conservation.
\end{abstract}

Keywords: Land Use, Land Cover, Neural Networks, Woodland, Deforestation

\section{Introduction}

Classified forests refer to areas that are officially protected for conservation purposes [1]. In Burkina Faso, these forests cover an area of 3.9 million hectares, representing about $14 \%$ of the national territory [2]. Recent reports suggest that the classified forests of Burkina Faso are subject to increasing and uncontrolled occupation causing significant changes in the vegetation cover [3-4]. In the southwestern region, high immigration of agro pastoralists from the north $[5,6]$ and emigration resulting from the crisis in Ivory Coast in 2002 [7] have increased pressure on the protected areas which are the mains areas of biodiversity conservation [8-9, 10]. In addition, West Africa is prone to droughts, irregular rainfall patterns and temperature increases with potentially degrading effects on ecosystem dynamics [11-12].

The classified forest of Koulbi (CFK) gained its protected status in 1955. Main threats to ecosystems conservation in this area include increasing yam production [13], intensified gold panning activities and climate disturbances. In order to plan and sustain the conservation of CFK, it is necessary to gather accurate data of vegetation cover changes and to understand the main causes of deforestation. Such information can facilitate decision making aimed at promoting sustainable management of 
the forest.

Satellite remote sensing has been demonstrated as an effective and low cost technique for studying land cover dynamics at different spatial scales. Regardless of the difficulties caused by spectral confusion in savanna type environments [14-15, 16], remote sensing of the vegetation cover can enable the accurate detection of land use/land cover (LULC) changes [17-18, 19].

The purpose of this study was to (i) map and quantify the LULC changes in CFK from 1986 to 2014 using Landsat imagery and (ii) determine the effects of climate and anthropogenic factors on the observed changes in CFK.

\section{Material and Methods}

\subsection{Study Area}

CFK is located in the province of Noumbiel, southwestern Burkina Faso, and covers an area of 40000 ha (Figure 1).
The CFK belongs to South-Sudanian climatic zone where the average annual rainfall is over $900 \mathrm{~mm}$ and the rainy season extends from June to September. Mean annual (1985-2014) rainfall and temperature in CFK are $1057 \mathrm{~mm}$ and $27.9^{\circ} \mathrm{C}$, respectively. The hydrographic network is dense and depends on the Mouhoun River, which forms a natural boundary between CFK and the republic of Ghana. According to Geographic Institute of Burkina Faso [20], soils are mostly found to be ferruginous, brown, eutrophic and ferralitic. The vegetation cover is mainly by savanna, but isolated areas of woodland dominated by Isoberlina spp. [21-22] and Anogeissus leiocarpa (DC) Guill. and Perr. are also common landscape features [23]. In 2014, the population of the Noumbiel province was estimated to be 89036 [2], mainly comprising farmers who cultivate yam as the most important cash crop. In addition, this area is favored by pastoralists and is experiencing increasing gold extraction activities.

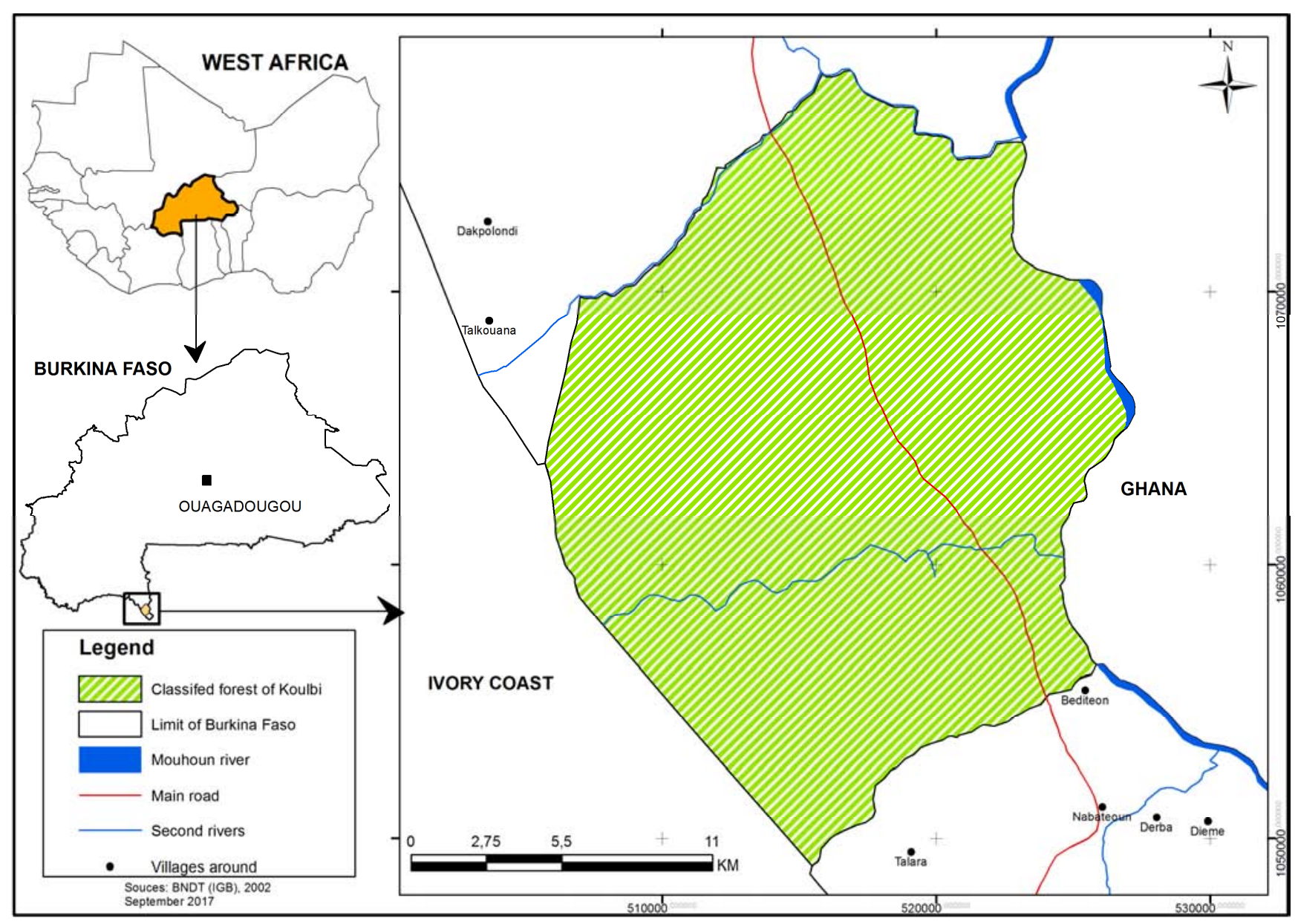

Figure 1. Location of the study site.

\subsection{Data}

Landsat images from Path195 and row53 were chosen. Two of them were Thematic Mapper (TM) images form $11 / 18 / 1986$ and $11 / 19 / 1998$ and one was Operational Land Imager (OLI) image from 10/30/2014. They were obtained from the United States Geological Survey (www.earthexplorer.usgs.gov/). Data from 277 randomly distributed floristic inventory plots were collected and used as reference data to facilitate the supervised classification of the Landsat imagery. Rainfall data from Batié pluviometric station (Noumbiel province) over the period 1985-2014 were obtained from the National Direction of Meteorology of Burkina Faso. In addition, a socio-economic survey was carried out in eight villages within a $5 \mathrm{~km}$ distance from the CFK, including Donsièrè, Fadio Gangalma, Kpéré, 
Médicateon, Poni, Téheni-sud and Titinateon. In each village, thirty households were chosen randomly and semi-structured interviews were conducted, resulting in a total of 240 respondents. The interviews focused on i) perceptions of degradation of the vegetation cover, ii) causes of the degradation, iii) yam production and its impact on vegetation, and iv) land abandonment caused by the population's eviction that occurred in 2009.

\subsection{Image Classification}

\subsubsection{Pre-processing}

The Landsat images were subject to radiometric and atmospheric correction in order to compensate for sensor noise, as well as atmospheric water vapor and aerosol contamination, using ENVI 5.1 software and Fast Line-ofsight Atmospheric Analysis of Spectral Hypercubes (FLAASH) [24-25, 26].

\subsubsection{Artificial Neural Network Classification}

Supervised classification of the Landsat imagery was conducted using Artificial Neural Networks (ANN), which has been shown to produce more accurate results in complex landscapes, such as savanna type environments, compared to conventional classification methods [27-28]. ANN is a multilayer perceptron and trained using the backpropagation method, a commonly used error-minimization technique. In this study, the structure of ANN was based on the input layers corresponding to the six Landsat bands, one hidden layer and output layers corresponding to the six LULC classes. Following [29] experiences, the back-propagation algorithm was implemented using five internal parameters. The learning rate (i) calculates the changes to be made to the weight values after each iteration. The momentum (ii), avoids the risk of error oscillation during learning process and measures the effect of a preceding iteration on the current iteration. The activation function (iii), often represented by a sigmoid or hyperbolic tangent, normalizes the values attributed to the neurons. The stop level (iv) varies between 0 and 1 and the iteration number $(v)$ is set by the user. In this study, ANN parameters were calibrated following the experiences of [28] in complex LULC, with the iteration number $=1000$, learning rate $=0.01$, momentum $=0.9$ and stop level $=0.1$.

The Landsat classification focused on six LULC classes, including gallery forest, woodland, tree savanna, shrub savanna, field and fallow and water. From the reference data, 152 plots were used for training the 2014 classification, and 125 plots were used for independent validation. For the 1986 and 1998 classifications, training and validation sites were selected from areas where no change had occurred during the study period. These areas were identified using the 2014's LULC map and LULC databases from 1992 and 2002 of IGB.

In order to reduce "salt and pepper effect" and to improve cartographic representation, a $3 \times 3$ median filter was applied to all classification results. Classification accuracy was assessed using standard metrics, including confusion matrix, Kappa coefficient and error curve.

\subsection{Analysis of Vegetation Cover Dynamics}

Surface area of the LULC classes for each year was calculated using ArcGIS 10.2 software. Change detection was conducted for three time periods (1986-1998, 1998-2014 and 1986-2014) using a transition matrix where LULC maps from two dates $\left(t_{0}\right.$ and $\left.t_{1}\right)$ are overlain. The output is a condensed square matrix describing the LULC changes during the considered period [30].

The annual average change rate for each LULC class was obtained using Equation 1 [31]:

$$
\mathrm{r}=\left(\frac{100}{t 2-t 1}\right) \mathrm{X} \ln \frac{A 2}{A 1}
$$

Where $r$ represents the annual variation rate for class $\mathrm{i} ; A_{1}$ is the surface area of $i^{\text {th }}$ class and at time $\mathrm{t}_{1}$ and $A_{2}$ is the surface area of class $i$ at time $t_{2}$.

\subsection{Calculation of Standardized Precipitation Index}

The amount and spatiotemporal distribution of rainfall control plant growth and need to be considered in an analysis of vegetation dynamics. We applied the Standardized Precipitation Index (SPI) to quantify rainfall shortages over defined time periods and related it to the observed vegetation dynamics; [32]. SPI was derived using Equation 2:

$$
\mathrm{SPI}=\frac{(\mathrm{Xi}-\mathrm{Xm})}{\mathrm{Si}}
$$

Where $X i$ represents annual rainfall in year $i$, whereas $X m$ and $S i$ represents mean and standard deviation of observed annual rain, respectively. The index values indicate details on the moisture or the environmental drought.

SPI $>2$ : Extreme Humidity (HE); 1<SPI $<2$ : High Humidity (HF); $0<\mathrm{SPI}<1$ : Fair Humidity $(\mathrm{HM}) ;-1<\mathrm{SPI}<0$ : Fair Drought (SM); -2<SPI $<-1$ : High Drought (SF); SPI $<-$ 2: Extreme Drought (SE).

\section{Results}

\subsection{Validation of Classification}

Accuracy assessment results showed that the overall classification accuracy was $83.0 \%, 86.3 \%$ and $87.2 \%$ for 1986, 1998 and 2014, respectively (Table 1). The error curves had a decreasing shape (Figure 2) indicating that error was minimized between calculated error and that expected during classification. The results show that spectral confusion occurred between galleries forest and woodland. This has contributed to the low classification accuracy for gallery forest (Table 1). 

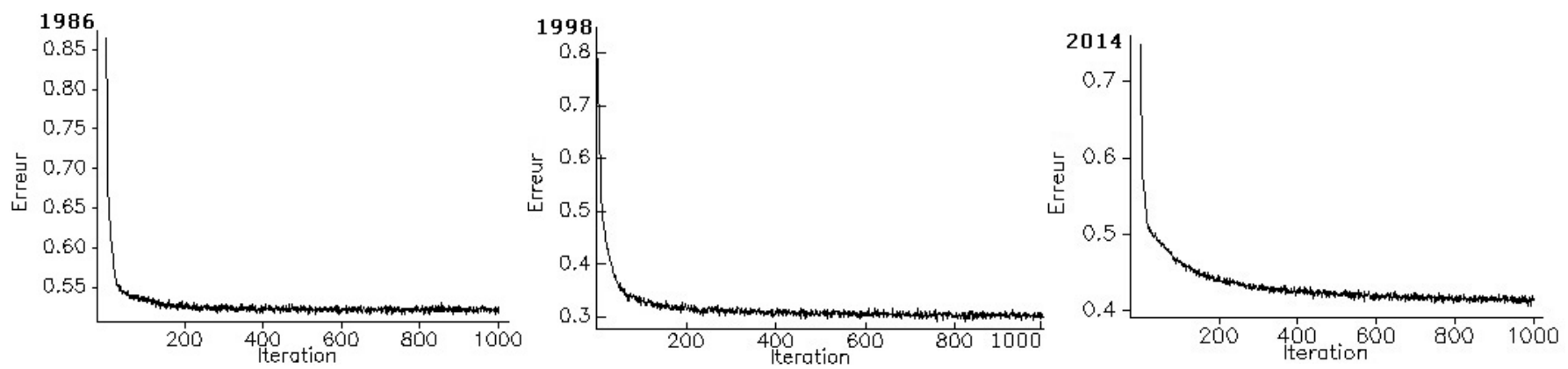

Figure 2. Curve of error derived from back-propagation Artificial Neural Network.

Table 1. Confusion matrix for classification of images from 1986, 1998 and 2014.

\begin{tabular}{|c|c|c|c|c|c|c|c|}
\hline LU/LC classes $(\%)$ & Ga.f & Wol & Tr.s & Sh.s & $\mathbf{F i} / \mathbf{f}$ & Wa.b & $\mathbf{C E}$ \\
\hline \multicolumn{8}{|l|}{ Year 1986} \\
\hline Ga.f & 71.78 & 29.98 & 3.55 & 0.10 & 00 & 00 & 31.84 \\
\hline Wol & 24.64 & 59.24 & 8.56 & 0.00 & 00 & 00 & 27.86 \\
\hline Tr.s & 3.38 & 10.58 & 85.03 & 5.25 & 00 & 00 & 13.44 \\
\hline Sh.s & 0.12 & 0.18 & 2.84 & 92.23 & 3.18 & 00 & 6.47 \\
\hline $\mathrm{Fi} / \mathrm{f}$ & 0.08 & 0.02 & 0.01 & 2.24 & 96.82 & 00 & 2.89 \\
\hline Wa.b & 00 & 00 & 00 & 00 & 00 & 100 & 00 \\
\hline Overall accuracy & 83.04 & & & & & & \\
\hline Kappa coefficient & 0.78 & & & & & & \\
\hline Omission Error & 28.22 & 30.76 & 14.97 & 7.77 & 3.18 & 00 & \\
\hline \multicolumn{8}{|l|}{ Year 1998} \\
\hline Ga.f & 60.05 & 19.10 & 7.19 & 0.49 & 00 & 00 & 27.55 \\
\hline Wol & 23.97 & 75.36 & 5.28 & 0.13 & 00 & 00 & 23.38 \\
\hline Tr.s & 14.11 & 5.39 & 80.45 & 11.55 & 0.06 & 0.20 & 19.21 \\
\hline Sh.s & 1.73 & 00 & 7.00 & 82.51 & 5.22 & 00 & 15.24 \\
\hline $\mathrm{Fi} / \mathrm{f}$ & 0.13 & 0.15 & 0.08 & 5.32 & 94.72 & 0.59 & 3.57 \\
\hline Wa.b & 00 & 00 & 00 & 00 & 00 & 99.21 & 00 \\
\hline Overall accuracy & 86.3 & & & & & & \\
\hline Kappa coefficient & 0.82 & & & & & & \\
\hline Omission Error & 34.95 & 24.64 & 19.55 & 17.49 & 5.28 & 0.79 & \\
\hline \multicolumn{8}{|l|}{ Year 2014} \\
\hline Ga.f & 80.00 & 8.46 & 2.76 & 0.22 & 00 & 00 & 29.92 \\
\hline Wol & 15.79 & 88.98 & 2.54 & 00 & 00 & 00 & 33.33 \\
\hline Tr.s & 2.83 & 2.56 & 85.13 & 4.66 & 0.08 & 00 & 5.38 \\
\hline Sh.s & 0.69 & 00 & 9.04 & 86.41 & 6.71 & 00 & 13.62 \\
\hline $\mathrm{Fi} / \mathrm{f}$ & 00 & 00 & 0.53 & 8.72 & 93.22 & 00 & 15.62 \\
\hline Wa.b & 0.69 & 00 & 00 & 00 & 00 & 100 & 1.68 \\
\hline Overall accuracy & 87.23 & & & & & & \\
\hline Kappa coefficient & 0.82 & & & & & & \\
\hline Omission Error & 20 & 11.02 & 14.87 & 13.59 & 6.78 & 00 & \\
\hline
\end{tabular}

Ga.f: gallery forest; Wol: Woodland; Tr.s: Tree savanna; Sh.s: Shrub savanna; Fi/f: Field/fallow; Wa.b: Water body; CE: commission error.

\subsection{Land Use/Land Cover Dynamics from 1986 to 2014}

The LULC maps of CFK (Figure 3) show the composition and configuration of the landscape. In 1986, the area was dominated by tree savanna $(46.0 \%)$ and woodland $(22.4 \%$; Figure 4). From 1986 to 1998, the woodland area experienced a strong decrease $(22.4 \%$ to $5.7 \%)$, whereas large increases in tree savanna (46\% to $58.4 \%)$, shrub savanna $(21.3 \%$ to $27.3 \%)$ and agricultural fields (4.6 to $6.1 \%$ ) were observed (Figure 4). In addition, between 1998 and 2014 the area of tree savanna decreased $(58.4 \%$ to $40.2 \%)$ and shrub savanna increased $(27.3 \%$ to $46.8 \%$; Figure 4). During the period 1986-1998, tree savanna was the dominant class, whereas shrub savanna dominated in the second period (1998-2014). 


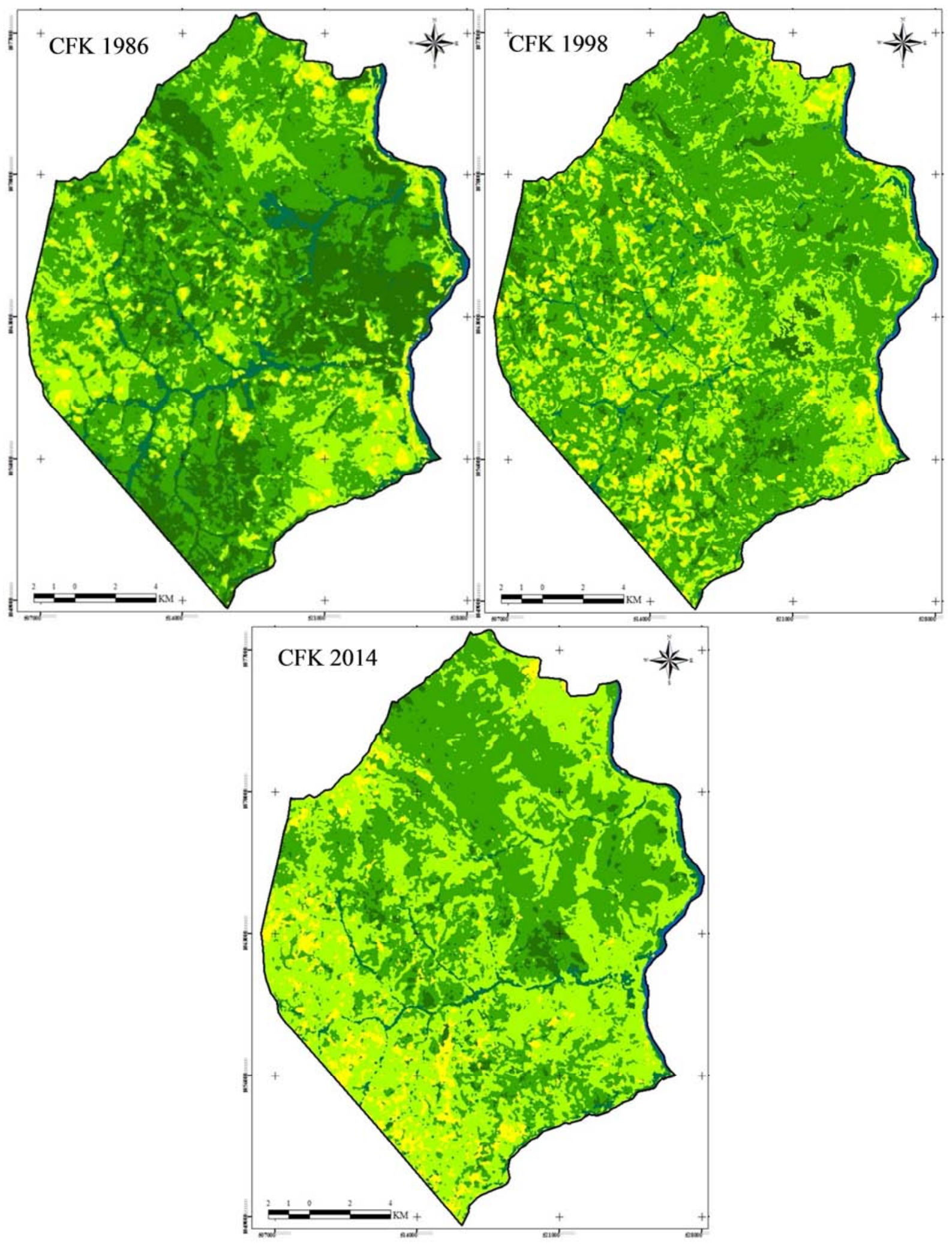

Gallery forest Woodland
Tree savanna

Shrub savanna
Field/fallow

Water body

Figure 3. Land use/Land cover maps of the classified forest of Koulbi. 

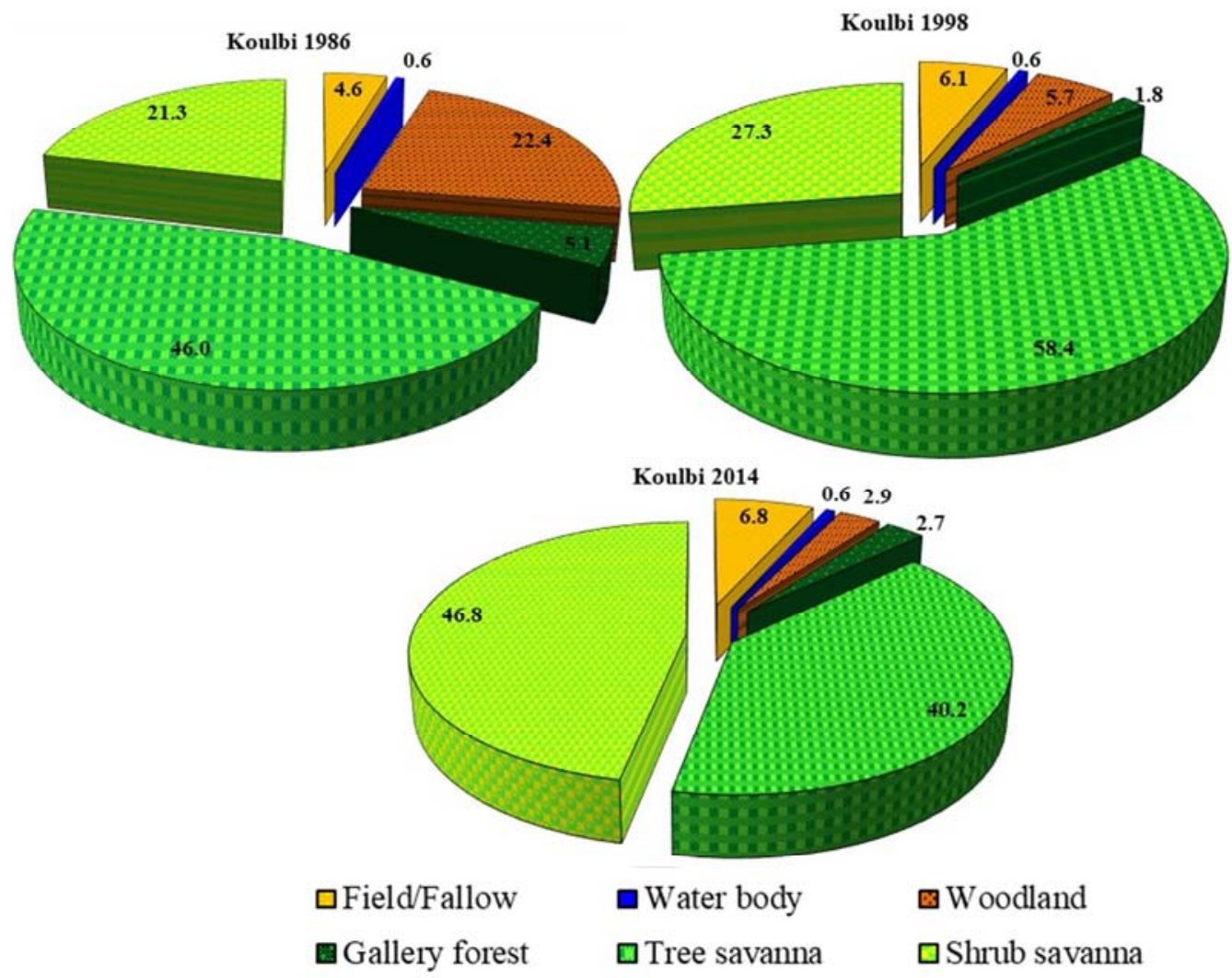

Figure 4. The state of land use/land cover classes area in 1986, 1998 and 2014.

The rate of LULC change (Table 2) showed that the woodland area decreased by 6600 ha from 1986 to 1998 , representing an annual loss of $11.4 \%$. A loss in woodland was also observed between 1998 and 2014, with an average decrease of $4.3 \%$ per year. In contrast, shrub savanna increased from $2.1 \%$ to $3.4 \%$ per year for the periods 1986 1998 and 1998-2014. The area of agricultural fields increased by $2.5 \%$ per year from 1986 to 1998 while it was stable from 1998 to 2014.

The tree savanna had an uneven variation during the two periods: it increased $2.0 \%$ per year from 1986 to 1998 , but decreased by $2.3 \%$ per year between 1998 and 2014 (Table 2).

Table 2. Land use/land cover dynamics.

\begin{tabular}{lllllll}
\hline Year & $\mathbf{1 9 8 6}$ 1998 & & 1998_2014 & & 1986_2014 \\
\cline { 2 - 7 } LU/ LC & change (ha) & r (\%) & change (ha) & R (\%) & change (ha) & R (\%) \\
\hline Gallery forest & -1293.89 & -8.62 & 371.47 & 2.62 & -922.42 & -2.20 \\
Woodland & -6600.68 & -11.36 & -1129.89 & -4.31 & -7730.57 & -7.33 \\
Tree savanna & 4884.26 & 1.98 & -7204.43 & -2.33 & -2320.17 & -0.49 \\
Shrub savanna & 2383.56 & 2.07 & 7703.04 & 3.36 & 10086.60 & 2.80 \\
Field/fallow & 624.07 & 2.47 & 260.80 & 0.64 & 884.87 & 1.42 \\
Water body & 2.68 & 0.09 & -0.98 & -0.03 & 1.70 & 0.03 \\
\hline
\end{tabular}

The loss of woodland (1986-1998) favored the development of tree savanna, which then underwent degradation to shrub savanna in the second period. Table 3 provides details about the loss of woodland and tree savanna during the study period. The main trend is a change from woodland to savanna. For the same time, $19.87 \%$ of shrub savanna in 2014 was tree savanna in 1986. Finally, shrub savanna area grew up and became the main matrix of CFK.

In summary, during these 28 years, the vegetation cover has experienced major changes. This shows that despite protection efforts, the CFK has degraded. The causes of this degradation are elucidated in the following sections. 
Table 3. Land use/land cover transition matrix (area \%) for observed time period (1986-1998-2014).

\begin{tabular}{|c|c|c|c|c|c|c|c|}
\hline & Ga.f & Wol & Tr.s & Sh.s & $\mathrm{Fi} / \mathbf{f}$ & Wa.b & Total \\
\hline 1986 & 2014 & & & & & & \\
\hline Ga.f & 1.24 & 0.20 & 1.12 & 2.15 & 0.12 & 0.01 & 4.84 \\
\hline Wol & 0.73 & 1.48 & 9.88 & 9.24 & 1.14 & 0.02 & 22.49 \\
\hline Tr.s & 0.45 & 0.89 & 21.67 & 19.87 & 3.26 & 0.00 & 46.15 \\
\hline Sh.s & 0.21 & 0.25 & 6.58 & 12.64 & 1.77 & 0.00 & 21.45 \\
\hline $\mathrm{Fi} / \mathrm{f}$ & 0.08 & 0.05 & 0.93 & 2.89 & 0.50 & 0.00 & 4.46 \\
\hline Wa.b & 0.02 & 0.00 & 0.00 & 0.00 & 0.01 & 0.58 & 0.61 \\
\hline 1986 & 1998 & & & & & & \\
\hline Ga.f & 1.01 & 0.15 & 2.60 & 1.00 & 0.06 & 0.01 & 4.84 \\
\hline Wol & 0.43 & 2.73 & 14.52 & 4.19 & 0.61 & 0.01 & 22.49 \\
\hline Tr.s & 0.23 & 2.30 & 29.80 & 10.89 & 2.93 & 0.00 & 46.15 \\
\hline Sh.s & 0.09 & 0.51 & 10.17 & 8.99 & 1.69 & 0.01 & 21.45 \\
\hline $\mathrm{Fi} / \mathrm{f}$ & 0.02 & 0.03 & 1.28 & 2.28 & 0.84 & 0.01 & 4.46 \\
\hline Wa.b & 0.01 & 0.00 & 0.01 & 0.00 & 0.00 & 0.58 & 0.61 \\
\hline Ga.f & 0.78 & 0.13 & 0.37 & 0.48 & 0.03 & 0.01 & 1.80 \\
\hline Wol & 0.22 & 0.77 & 2.82 & 1.61 & 0.30 & 0.00 & 5.72 \\
\hline Tr.s & 1.28 & 1.34 & 27.03 & 25.57 & 3.15 & 0.01 & 58.37 \\
\hline Sh.s & 0.43 & 0.59 & 8.72 & 15.30 & 2.31 & 0.00 & 27.35 \\
\hline $\mathrm{Fi} / \mathrm{f}$ & 0.02 & 0.05 & 1.24 & 3.83 & 1.00 & 0.00 & 6.15 \\
\hline Wa.b & 0.01 & 0.00 & 0.00 & 0.01 & 0.01 & 0.58 & 0.61 \\
\hline Total & 2.74 & 2.87 & 40.18 & 46.80 & 6.80 & 0.61 & 100 \\
\hline
\end{tabular}

Ga.f: gallery forest; Wol: Woodland; Tr.s: Tree savanna; Sh.s: Shrub savanna; Fi/f: Field/fallow; Wa.b: Water body

\subsection{Climatic Causes}

SPI derived from a 30-year rainfall time series show that CFK experienced 4 years of high drought (HD), 14 years of fair drought (FD), 6 years of fair humidity $(\mathrm{FH})$ and 6 years of high humidity $(\mathrm{HH})$. Overall, drought years (18) were more frequent than humid years (Figure 5), indicating that the area tends to be arid.
A decade scale analysis showed a 5-year fair drought from 1985-1994. The period 1995-2004 showed a 2-year high drought and 5-year fair drought. For the decade 2005-2014, we noted 2-year high drought and 4-year fair drought. The global trend showed that more than half of each decade was found to be drought years.

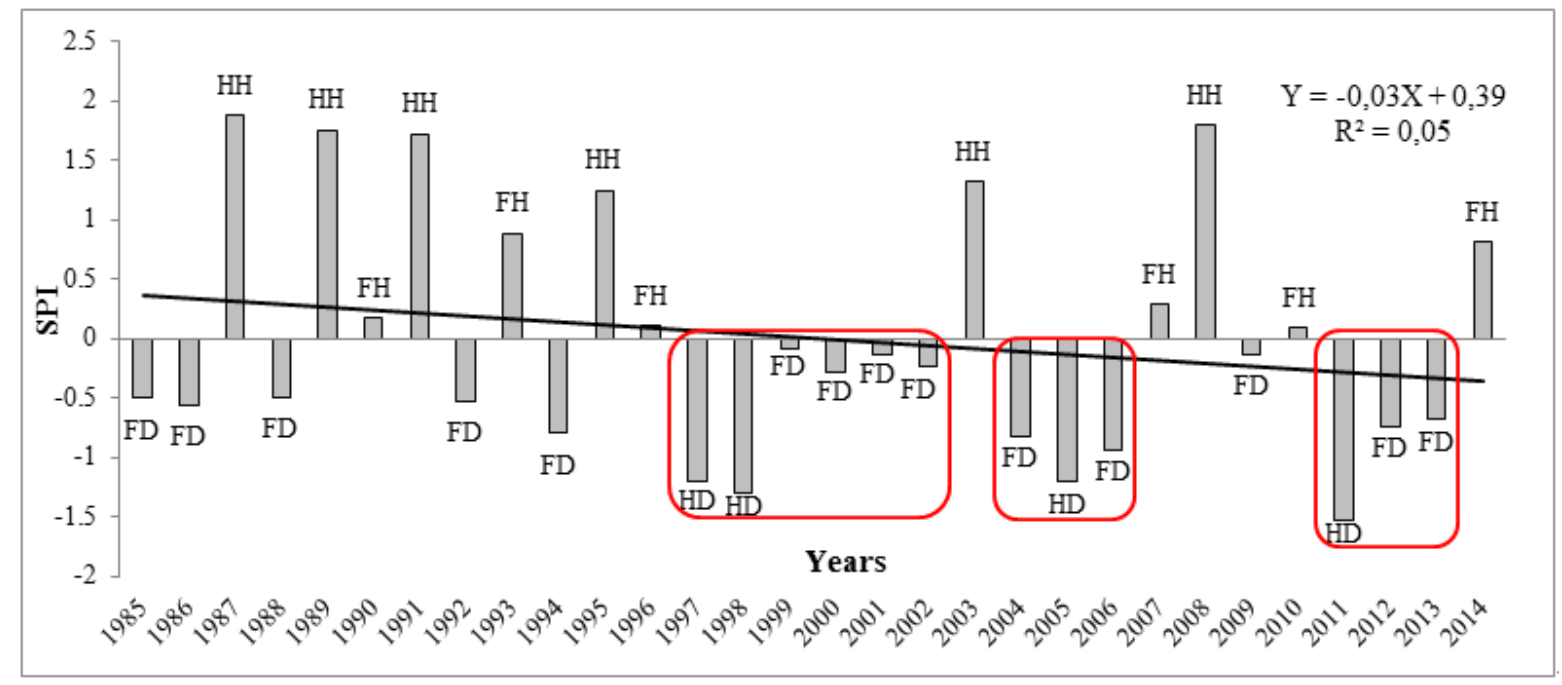

HD: hight drought, FD: fair drought, FH: fair humidity, HH: high humidity

Figure 5. Variation curve of the standardized precipitation index (SPI).

\subsection{Local Perceptions}

The degradation of the vegetation cover in CFK was noted by $95 \%$ of the respondents who attributed it to different factors, including demographic pressure (97\%), bush fires
(93\%), transhumance (89\%), yam cultivation (88\%) and climate change (69\%). More than $50 \%$ of survey respondents confirmed their stay in the classified forest before 2009 (Table 4). In Poni and Gangalma villages, respectively 93\% and $83 \%$ of the respondents are former inhabitants of CFK. 
The results suggest that the deforestation increased as a result of increasing yam production. Indeed, $62 \%$ of the respondents are found to be yam producers, among which $97 \%$ stated that after a year of production, the soil tends to be inappropriate for yam cultivation. These fields are instead used for the cashew (Anacardium occidentale L.) cultivation
(Figure 5c) and other activities for the coming season. The abandoned fields in the CFK consecutive to the population's eviction are estimated to 1676.7 ha (Table 4). Producers practice slash-and-burn shifting agriculture where the burned trees are used as support for yam (Figures $6 \mathrm{a}$ and $6 \mathrm{~b}$ ).

Table 4. The land use for human activities and its impact on the classified forest of Koulbi.

\begin{tabular}{lllllllll}
\hline Villages & Don & Fad & Gan & Kpé & Méd & Pon & Téh & Tit \\
\hline Farmer occupants (\%) & 70 & 13.33 & 83.33 & 6.67 & 53.33 & 93.3 & 60 \\
Areas (ha) & 171 & 49 & 458.25 & 20 & 285 & 195 & 214.50 & 284 \\
\hline
\end{tabular}

Don: Donsièrè; Fad: Fadio; Gan: Gangalma; Kpé: Kpéré; Méd: Médicateon; Pon: Poni; Téh: Téheni-sud; Tit: Titina

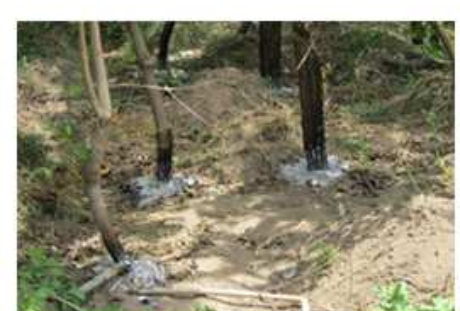

a. Ecobuage

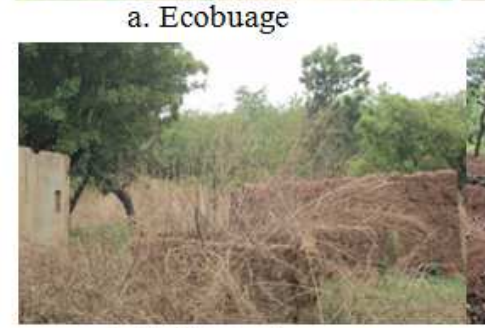

d. Habitat ruin

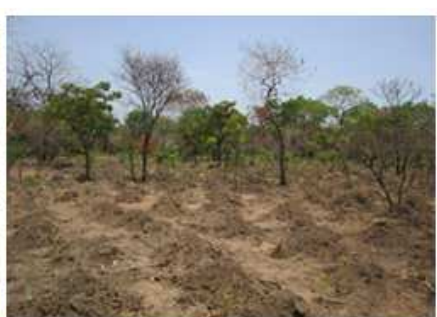

b. Yam butts

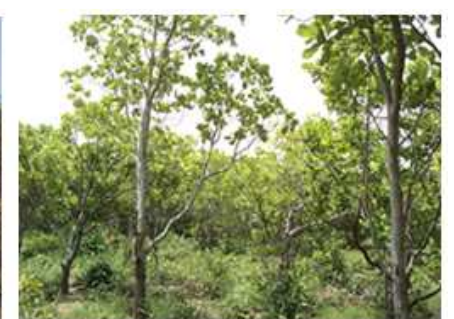

c. Anacardium plantation
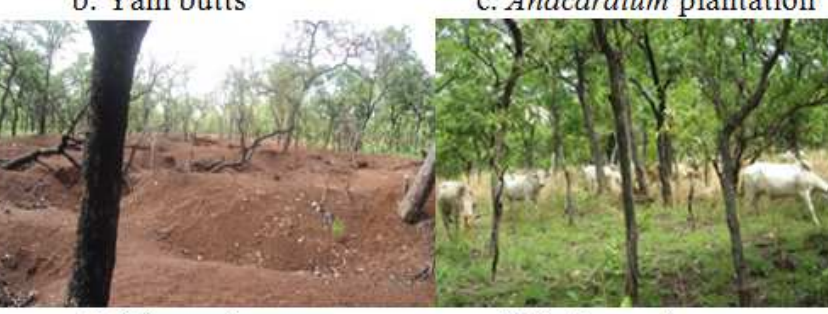

e. Gold panning

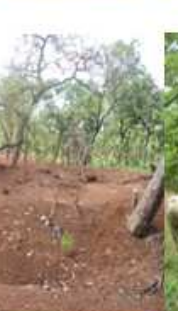

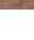
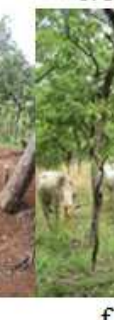

Figure 6. Effects of anthrogenic pressures on classified forest of Koulbi.

\section{Discussion}

\subsection{Validation of Classification}

The overall accuracies of the classification and the kappa coefficients showed that the supervised classification resulted in a successful mapping of the LULC (1986, 1998 and 2014) in the CFK. The decreasing error curves confirmed the confusion matrix values, revealing that the classification was sufficiently accurate [28]. The confusion between gallery forest and woodland can be explained by the similar spectral properties of these two classes. Woodlands, especially those dominated by Anogeissus leiocarpa, were found in depressions and along water bodies [23] and tended to be mixed up with the gallery forest areas. In the Sudanian zone, mixed vegetation and bush fires often contribute to an increased spectral confusion [33]. This phenomenon was observed in this study where the limit between different savanna classes was very subtle. An increased number of training areas and the use of historical land cover data contributed to reducing the classification error [34].

\subsection{Land Use/Land Cover Dynamics}

The CFK has experienced major changes of the LULC between 1986 and 2014. A substantial increase in the area of the savanna classes area as a result of the decreasing woodland which is considered as islets [23]. A significant degradation of the primary vegetation cover has occurred during the last three decades with a large increase of shrub savannas and agricultural fields. The reduction of closed forests and increase of open tree cover classes has been reported in other areas of the Sudanian zone of Burkina Faso, including Sissili province, the Bontioli wildlife reserve and the classified forest of Tiogo [3-35, 4]. The leading causes of shrub savannas development were that woodlands and trees savannas were either cleared for agricultural activities or subjected to selective wood cutting. The observed increase in agricultural fields between 1986 and 1998 was confirmed by the socio-economic survey which revealed a high land use in the forest before the people eviction that occurred in 2009 . More than $50 \%$ of the respondents admitted to use protected land in the CFK. Results from this study show that an increasing area of land has been used for yam cultivation, which requires more space since yam fields are usually abandoned after a single production cycle. After the governmental decision to evict people from CFK, the formerly cultivated spaces were transformed into shrub savanna. Several authors [35-33, 36] reported that pressures from land use and settlements were among the leading causes of the fragmentation of homogeneous ecosystems.

The SPI analysis suggests that CFK has experienced 
decreasing rainfall since the 1970 s. These results are in accordance with evidence reported by [37-38, 39] in other places in West Africa. For the period covered by this study, twenty-four (24) years of rain shortage were observed. The decreased rainfall along with sequential droughts may have disrupted the woody cover. Indeed, [40-41] reported that an isolated year of drought, even if extreme, often cause less negative effects to the woody vegetation than a two-year (or more) consecutive fair droughts. According to these authors, the persistence of even fair droughts would be a major risk in terms of tree cover degradation. The rain shortage reduces the forest and savanna ecosystems [42], increases the negative effects of bush fires [43] and affects the establishment or the recruitment of woody species as well as the natural regeneration [44].

\section{Conclusion}

This study analyzed the effects of climate and anthropogenic factors on landscape dynamics in the CFK. It enabled the quantification of the ongoing major changes and disentangled the effects of human activities and climate on the decreasing vegetation cover. The period 1986-1998 was characterized by a high decrease of the woodland area as a result of the increased trees savanna. From 1998 to 2014, the area of tree savanna also experienced a high decrease resulting from the increased of shrub savanna and that of the fields.

The study revealed that the forest was under high land use before 2009 and more than $50 \%$ of the survey respondents in the villages have confirmed to be former inhabitants in the CFK. Moreover, the high yam production was responsible for the degradation of the forest. Regarding the impact of climate, it was found that during a 30 -year period, this region was dominated by high numbers of drought years (18 droughts). The observed increasing agricultural fields in 2014 and that of recurring gold panning activities in CFK despite the fact that population was forced to move by government suggested that focus should be on the monitoring of this forest by forest officials.

\section{Acknowledgements}

The authors acknowledge the financial support of UNDESERT - Understanding and Combating Desertification to Mitigate its Impact on Ecosystem Services (EU-FP7 no. 243906). We also thank the inhabitants of Batié and Kpéré.

\section{Conflicts of Interest}

The author declares that there is no competing of interest.

\section{References}

[1] Code forestier, 2011. Loi $\mathrm{N}^{\circ} 003-2011 / \mathrm{AN}$ portant Code forestier au Burkina Faso. http://www.legiburkina.bf/Documents/CODE\%2520FORESTI ER.pdf [le 19 Décembre 2017].
[2] INSD 2015. Institut national de la statistique et de la démographie, Annuaire statistique 2014. Ministère de l'économie et des finances, Burkina Faso. 376 p.

[3] Dimobé, K., Ouédraogo, A., Soma, S., Goetze, D., Porembski, S., et Thiombiano, A,. 2015. Identification of driving factors of land degradation and deforestation in the Wildlife Reserve of Bontioli (Burkina Faso, West Africa). Global Ecology and Conservation 4, 559-571. http://dx.doi.org/10.1016/j.gecco.2015.10.006.

[4] Tankoano, B., Sanon, Z., Hien, M., Dibi, N. H., Yameogo, J. T., et Somda, I., 2016. Pression anthropique et dynamique végétale dans la forêt classée de Tiogo au Burkina Faso: apport de la télédétection. TROPICULTURA, 02 (34): 193-207.

[5] Balma, D., Bognounou, O., Ouédraogo, A., Tankoano, M. J., Zigani, G., et Zigani, M., 2004. La diversité biologique agricole au Burkina Faso. Disponible à http://www.fao.org/docrep/008/y5667f/y5667f0i.htm [le 12 Juin 2017].

[6] Ouédraogo, I., Savadogo, P., Tigabu, M., Cole, R., Odén, P. C., et Ouadba, J.-M. 2009. Is rural migation a threat to environmental sustainability in southern Burkina Faso? Land Degrad. Develop. 20: 217-230. DOI: 10.1002/Idr.910.

[7] Courtin, F., Fournet, F., et Solano, P., 2010. La crise ivoirienne et les migrants Burkinabés: l'effet boomerang d'une migration internationale. Afrique Contemporaine, 236, 13-27. http://www.documentation.ird.fr/hor/fdi: 010065014

[8] Ouoba, P., 2006. Flore et végétation de la forêt classée de Niangoloko, sud-ouest du Burkina Faso. Thèse de Doctorat, Université de Ouagadougou (Burkina Faso).

[9] Ouédraogo, O., 2009. Phytosociologie, dynamique et productivité de la végétation du parc national d'Arly (Sud-Est du Burkina Faso). Thèse de doctorat unique, Université de Ouagadougou (Burkina Faso).

[10] Nacoulma, B. M. I., 2012. Dynamique et stratégies de conservation de la végétation et de la phytodiversité du complexe écologique du Parc national du W du Burkina Faso. Thèse de doctorat, Université de Ouagadougou (Burkina Faso).

[11] Adjonou, K., Bellefontaine, R., Kokou, K., 2009. Les forêts claires du Parc national Oti-Kéran au Nord-Togo: structure, dynamique et impacts des modifications climatiques récentes. Sécheresse, 20 (1 e): e1-e10.

[12] Belle, E. M. S., Burgess, N. D., Misrachi, M., Arnell, A., Masumbuko, B., Somda, J., Hartley, A., Jones, R., Janes, T., McSweeney, C., Mathison, C., Buontempo, C., Butchart, S., Willis, S. G., Baker, D. J., Carr, J., Hughes, A., Foden, W., Smith, R. J., Smith, J., Stolton, S., Dudley, N., Hockings, M., Mulongoy, J., et Kingston, N., 2016. Impacts du changement climatique sur la biodiversité et les aires protégées en Afrique de l'Ouest, Résumé des résultats du projet PARCC, Aires protégées résilientes au changement climatique en Afrique de l'Ouest. UNEP-WCMC, Cambridge, UK.

[13] Bouché, P., 2007. Inventaire de la faune dans la forêt classée de Koulbi et dans les réserves Partielle et Totale de Bontioli. Rapport, Ministère de l'Environnement et du Cadre de Vie, Burkina Faso. 32 p.

[14] Tia, L., 2007. Modeling of vegetation dynamics and its contribution to the water balance in semi_arid of West Africa. $\mathrm{PhD}$ thesis. Rheinischen Friedrich-Welhelms-Universität Bonn, (Germany). 
[15] Ouédraogo, I., Tigabu, M., Savadogo, P., Compaoré, H., Odén, P. C., et Ouadba J. M., 2010. Land cover change and its relation with population dynamics in Burkina Faso, West Africa. Land Degrad. Develop.5 (21): 453-462. doi: 10.1002/Idr.981.

[16] Tankoano, B., Hien, M., Dibi, N. H., Sanon, Z., Yaméogo, J. T., et Somda, I., 2015. Dynamique spatio-temporelle des savanes boisées de la forêt classée de Tiogo au Burkina Faso, International Journal of Biological and Chemical Sciences, 04 (09): 1984-2000.

[17] Inoussa, M. M., Mahamane, A., Mbow, C., Saadou, M., Bachmann, Y., 2011. Dynamique spatio-temporelle des forêts claires dans le Parc national du W du Niger (Afrique del'Ouest). Sècheresse 02 (22): 108-16. doi: 10.1684/sec.2011.0305.

[18] Toko, M. I., Touré, F., Imorou, I. T., et Sinsin, B., 2012. Indices de structures spatiales des îlots de forêts denses dans la région des Monts Kouffé, VertigO - la revue électronique en sciences de l'environnement, 03 (12): 1-17. dio: $10.4000 /$ vertigo. 13059 .

[19] Adimasu, W. W., 2016. Land Use Land Cover Change Detection by Using Remote Sensing Data in Akaki River Basin. International Journal of Environment, Agriculture and Biotechnology.1 (1): 1-10.

[20] IGB 2015. Institut Géographique du Burkina, Document de spécifications externes de contenu de la Base Nationale de Données Topographiques (BNDT), 1-85.

[21] Fontès, J., et Guinko, S., 1995. Carte de la végétation naturelle et de l'occupation du sol du Burkina Faso / ICIV. Université de Toulouse, Université de Ouagadougou, IRBET et MET.

[22] Sanon, Z., Yameogo, J. T., Rabiou, H., Hien, M., 2019. Effects of anthropogenic pressure on stands of Isoberlinia doka Craib and Stapf and Isoberlinia tomentosa (Harms) Craib and Stapf in the Sudanian zone of Burkina Faso. International Journal of Biological and Chemical Sciences 07/2019; 13 (2): 911924., DOI: 10.4314/ijbcs.v13i2.27.

[23] Sanon, Z., Hien, M., Yaméogo, J. T., Bachmann, Y., et Somda, I., 2015. Dynamique structurale des îlots de forêt claire à Anogeissusleiocarpa (DC.) Guill. et Perr. dans le Sud-Ouest du Burkina Faso. Int. J. Biol. Chem. Sci. 02 (9): 847-860. http://ajol.info/index.php/ijbcs.

[24] Arabi, B., Salama, S., Mhd, Wernand, M. R., Verhoef, W., 2016. MOD2SEA: A coupled atmosphere-hydro-optical model for retrieval of chlorophyll-a from remote sensing observationsin complex turbid waters. Remote Sensing, 722 (8): 1-22. https://www.mdpi.com/2072-4292/8/9/722/htm.

[25] Rosas, J., Houborg, R., Mc Cabe, M. F., 2017. Sensivity of Landsat 8 surface temperature estimates to atmospheric profile data: a study using MODTRAN in Dryland irrigated systems. Remote Sensing, 988 (9): 1-27. https://www.mdpi.com/20724292/9/10/988/htm.

[26] Kyale, K. J., Wardell D. A., Mikwa, J-F., Kabuanga, J. M., Monga, N. A., Maindo, OJ., Doumenge C,. 2019. Dynamique de la déforestation dans la Réserve de biosphère de Yangambi (République démocratique du Congo): variabilité spatiale et temporelle au cours des 30 dernières années. Bois et Forêts des Tropiques, 341: pp. 15-28. https://doi.org/10.19182/bft2019.341.a31752.

[27] Mustapha, M. R., Lim, H. S., and MatJafri, M. Z., 2012.
Analysis of Land Cover Classification in Arid Environment: A Comparison Performance of Four Classifiers, Earth and Planetary Sciences» Geology and Geophysics» "Remote Sensing of Planet Earth", book edited by Yann Chemin, chapter 6, 118-142. doi: 10.5772/33679.

[28] Jofack-Sokeng, V. C., Kouamé, F. K., Dibi, N. H., Tankoano, B., Akpa, You L., and Ngounou N. B., 2016. Cartographie de l'Occupation de sol des Hauts Plateaux de l'Ouest Cameroun par réseaux de neurones appliqués à une image LANDSAT 8 OLI. International Journal of Innovation and Scientific Reserch, 02 (23): 443-454.

[29] Zhou, L., et Yang, X., 2008. Use of neural networks for land cover classification from remotely sensed imagery. The International Archives of the Photogrammetry, Remote Sensing and Spatial Information Science, (37): 575-578.

[30] Bamba, I., Mama, A., Neuba, D. F. R., Koffi, K. J., Traoré, D., Visser, M., Sinsin, B., Lejoly, J., et Bogaert, J., 2008. Influence des actions anthropiques sur la dynamique spatiotemporelle de l'occupation du sol dans la province du BasCongo (R. D. Congo). Sciences \& Nature Vol.5 N¹: 49-60.

[31] Puyravaud, J. P., 2003. Standardizing the calculation of the annual rate of deforestation, Forest Ecology and Management, 177: 593-596.

[32] Bergaoui, M., et Alouini, A., 2001. Caractérisation de la sécheresse météorologique et hydrologique: Cas du bassin versant de Siliana en Tunisie. Sécheresse 04 (12): 205-213. $\mathrm{http}: / / \mathrm{www} . j \mathrm{le.com} / \mathrm{fr} / \mathrm{revues} / \mathrm{sec} /$ edocs/caracterisation_de_la secheresse meteorologique et hydrologique cas du bassin versant_de_siliana_en_tunisie_230049/article.phtml?tab=texte [le 16 Juin 2017].

[33] Mama, A., Sinsin, B., De Cannière, C., et Bogaert, J., 2013. Anthropisation et dynamisation des paysages en zone soudanienne au nord du Bénin, Tropicultura, 01 (31): 7888.

[34] Kabba, S. T. V., and Li, J., 2011. Analysis of land use and land cover changes, and their ecological implication in Wuhan, China, Journal of Geography and Geology, (3): 104-118.

[35] Paré, S., Söderberg, U., Sandewall, M., Ouadba, J. M., 2008. Land use analysis from spatial and field data capture in southern Burkina Faso, West Africa. Agriculture, Ecosystems and Environment 127: 277-285. doi: 10.1016/j.agee.2008.04.009.

[36] Sadda, A-S., Diouf, A., Lawali, S., Ouedraogo, M., Bogaert, J., et Mahamane, A., 2016. Pression anthropique et dynamique paysagère en zone rurale semi-aride: cas de la commune de Tibiri, région de Maradi (Niger). TROPICULTURA, 02 (34): 127-139.

[37] Traoré, S. B., Reyniers, F. N., Vaksmann, M., Koné, B., Sidibé, A., et Yoroté, A., 2000. Adaptation à la sécheresse des écotypes locaux de sorghos du Mali. Sécheresse, 11 (3): 227237.

[38] Ozer, P., Hountondji, Y. C., Niang, A. J., Karimoune, S., Manzo, O. L., et Salmon, M., 2010. Désertification au Sahel: historique et perspectives. BSGLG, 54: 69-84.

[39] Kouassi, A., M., Kouamé, K. F., Ahoussi, K. E., Oularé, S., et Biemi, J., 2012. Impacts conjugués des changements climatiques et des pressions anthropiques sur les modifications de la couverture végétale dans le bassin versant du N'zi-Bandama (Côte d'Ivoire), Rev. Ivoir. Sci. Technol., (20): 124-146. 
[40] Gareyane, M., 2008. La sédentarisation des nomades dans la région de Gao. Révélateur et déterminant d'une crise multidimensionnelle au Nord Mali. Thèse de doctorat, Université Jean Moulin Lyon 3, Lyon, France, 287p.

[41] Diallo, H., Bamba, I., Barima, Y. S. S., Visser, M., Ballo, A., Mama, A., Vranken, I., Maïga, M., et Bogaert, J., 2011. Effets combinés du climat et des pressions anthropiques sur la dynamique évolutive de la végétation d'une zone protégée du Mali (Réserve de Fina, Boucle du baoulé). Sécheresse, 22 (3): 97-107.

[42] Brou, T. Y., 1997. Analyse et dynamique de la pluviométrique en milieu forestier Ivoirien: recherche de corrélations entre les variables climatiques et les variables liées aux activités anthropiques. Thèse de doctorat, Université de Cocody, Abidjan (Côte d'Ivoire).
[43] Koné, M., Aman, A., Yao, A. C. Y., Coulibaly, L., et N'Guessan, K. E., 2007. Suivi diachronique par télédétection spatiale de la couverture ligneuse en milieu de savane Soudanienne en Côte d'Ivoire. Télédétection, 1-2-3-4 (7): 433-446.

[44] Alvarado, S. T., 2012. Evaluation du rôle des feux de brousse sur la composition, la structure, la phénologie, et la résistance de la végétation des bois de tapia (Uapacabojeri) du massif d'Ibity, Nouvelle Aire Protégée, en vue de sa gestion durable. Thèse de doctorat sciences et Agro science, Département de Biologie et l'Ecologie Végétales, de l'Université d'Avignon, Antananarivo (Madagascar). 